\title{
SME INTER-CLUSTERING LINKAGE OF EAST JAVA: AMONG BUSINESS STRATEGY AND COOPERATIVES \\ Deni Aditya Susanto*
}

\author{
*Master of Economics Development, Universitas Gadjah Mada, Indonesia
}

\begin{abstract}
The Indonesian SME cluster has not fully implemented the cluster concept, causing the SME cluster to stagnate. The Meubel SME Cluster of Pasuruan City and Malang City are two prime clusters working to show their economic crisis performance several times. This study aims to examine the factors of inter-firm linkage and business strategy on business performance. Methodologically, this study uses several analytical methods, namely multiple linear regression, to measure the influence between inter-firm linkage and business strategy variables on business performance, SWOT matrix to map strategy, and descriptive analysis to present non-parametric findings. This study analyzed 60 samples of MSEs from a population of 350 business units. The results of the study mentioned that aspects of business strategy (finance, marketing, human resources, research, development, and operations) had a more significant effect on business performance (sales, profits, assets, labor, and productivity) than inter-firm linkage (backward, forward, and horizontal). Through SWOT matrix analysis, the inter-clustering linkage of Malang City and Pasuruan cluster SMEs is naturally created. Access to raw materials and labor in the city of Malang began to be complicated even though consumers' potential from large tourists and access to adequate technology. In contrast, Pasuruan City is It to do marketing because of geographical conditions' weakness even though the raw material resources and labor are abundant. The specialization of production is created with Pasuruan City as the production base and Malang City as the Marketing Base.
\end{abstract}

\section{ARTICLE INFO}

Received: May $2^{\text {nd }}, 2020$

Revised: March $11^{\text {th }}, 2021$

Accepted: May $8^{\text {th }}, 2021$

Online: November $25^{\text {th }}, 2021$

${ }^{*}$ Correspondence:

Deni Aditya Susanto

E-mail:

deniaditya.s@gmail.com

Keywords: Cooperatives, Business Strategy, Inter-Clustering Linkage

JEL: Q13, L21, C38

To cite this document: Susanto, D. A. (2021). SME Inter-Clustering Linkage of East Java: Among Business Strategy and Cooperatives. JDE (Journal of Developing Economies), 6(2), 174-185

\section{Introduction}

Industrial economics research, tiny industry or small and medium enterprises (SMEs), is becoming an essential part of economic development. In developing countries, SMEs dominate the workforce at least 75 percent of the total workforce absorbed each year (Kusumah \& Fetriyuna, 2014). Nonetheless, SMEs' complex problem makes it a challenge for policy authorities to take strategic steps to develop it. Mawardi, Choi, \& Perera (2011) argues that the main threats and obstacles to SMEs always lie in bureaucratic inefficiencies, tax injustice, poor public infrastructure, low access to formal financial institutions, low skilled human resources, and poor technological capabilities that are mastered. Then, in 2001, the United Nations Industrial Development Organization (UNIDO) formulated an SME solution in a study that was eventually referred to as a cluster model. 
The cluster on SMEs (SME cluster) is a collective action carried out by a group of SMEs that form a geographical agglomeration by uniting a common business agenda (UNIDO, 2001). Saraceni \& de Andrade Júnior (2012) suggested the cluster as an increase in SMEs' capacity, which had been very small. Joint actions of SME clusters can provide solutions in the form of collective inputs (mainly raw materials), collective marketing, research, and technology development (Belete, 2018). However, not all developing countries have been able to transform SME clusters to increase their capacity and competitiveness, one of which is Indonesia. Indonesia according to Setyawan Agus et al., (2015) has not been able to implement clusters as a concept of the production value chain to achieve SMEs' collective efficiency.

The SME cluster has two main concepts, namely internal cluster collaboration or what is referred to as inter-firm linkage and individual business strategies (Hoetoro, 2017). Some Indonesian SME clusters have not been able to apply these two concepts, apart from limited access to information and training and inadequate human resource structures to develop strategies and cooperation (Setyawan Agus et al., 2015). Tambunan (2008) suggests that the internal cluster's cannibalistic character is a significant problem for SMEs. SMEs are faced with competition from various directions within the internal SMEs and externally with other clusters and large businesses. This inter-firm linkage and business strategy mapping have not been translated into practical and technical steps, so that the cluster mechanism cannot work correctly (Hoetoro \& Aditya Susanto, 2018).

This research focuses on inter-firm linkage and SME cluster business strategies that have excellent performance, with the most straightforward indicator of their ability to survive amid a crisis. Velmurugan (2017) explained that the global financial crisis that occurred both on a global and regional scale could quickly kill SMEs, except SMEs with solid structures on the network side, workforce skills, business financial structure, and innovation exploiting opportunities. Pasuruan Meubel UKM Cluster and Malang Meubel UKM Cluster have been more than 40 years old, going through several crises. Both showed excellent performance in networking and business strategy so that the cooperation model and business strategy in becoming an alternative reference in the development of SME clusters.

The purpose of this study is to measure the significance of aspects of inter-firm linkage and business strategies to survive and improve cluster performance. On the other hand, mapping strengths, weaknesses, opportunities, and threats are carried out to determine the position and strategy of optimizing various factors for developing business prospects. Finally, empirical findings that are conceptually able to improve performance will be described to provide a clear and constructive picture for the SME cluster development model. The conclusions of this study contribute to providing policy recommendations for SME cluster development. It is done through interventions on the key factors that most influence business performance. Also, it can develop SME cluster policies SME inter-clustering linkage that can optimize each SME cluster's potential and performance.

\section{Literature Review}

\section{Inter-Firm Linkage as Collective Efficiency}

An inter-firm linkage connects SME cluster members to streamline costs to be effective in conducting business activities. According to (Hoetoro, 2017), the inter-firm linkage is a joint working mechanism between SMEs by equalizing the work rhythm of business organizations. This collaboration includes purchasing raw materials together, developing a joint workforce, promoting and comparing together, and other business operational agendas. Hoetoro \& Aditya Susanto (2018) break down inter-firm linkage components into three main lines: backward linkage, forward linkage, and horizontal linkage. Backward linkage is a relationship between SMEs in one cluster to build a network backward (Navas-Alemán, Pietrobelli, \& Kamiya, 2012). 
Furthermore, this relates to the network of procurement of raw materials, human resources, access to financial capital, to access to the latest technology. Backward linkage plays an essential role in ensuring that SME clusters have guaranteed input with optimum cost-efficiency, accompanied by sustainability and guarantee.

Next, forward linkage supports the future relationship of SME clusters with marketing and consumer networks. Urban et al., (2000) emphasized that forward linkage is divided into several aspects: network marketing partners, sales distribution, advertising, promotion, and product exhibitions. SMEs' main problem lies in marketing and the accompanying innovations, including the low advertising and branding innovations, marketing and financing budget strategies, to the stagnation of partnership networks (Aguilera-Castro \& Virgen-Ortiz, 2016). Forward linkage in the SME cluster enables future marketing and network capacity to increase significantly. It is based on joint action to build geographical agglomeration branding, develop tourist destination patterns, and advertising cost efficiency (Najib, Kiminami, \& Yagi, 2011).

Finally, Horizontal linkage is a network and network aligned or aligned in the middle of an SME cluster. According to Tambunan (2006), SMEs' small capacity is enlarged through internal cluster collaboration through suborder and subcontracting lines. It will eliminate SME production constraints, namely the inability of SMEs to meet the standard quantity of orders. Furthermore, there is another crucial impact factor in the horizontal linkage process, namely knowledge spill-over. UNICO (2011) states that knowledge spill-over is a distribution of knowledge and expertise in the middle of a cluster of collaborative processes and product innovation. It also allows technology and production devices to be deployed naturally.

\section{Business Strategy of SME Cluster}

Strategy SME cluster business has a different pattern from the industry in general. Due to SMEs' limitations to several aspects of the business, so relevant business strategies need to be adjusted to the SME business structure. Kokobe Seyoum Alemu, B \& Seyoum Alemu (2015) divides SMEs' characteristics into several aspects, including limited financial capital, low quality of labor, narrow marketing reach, simple production technology, and conventional operational performance. So, the business strategy factors consist of financial, marketing, human resources, research and development, and operational strategies (Blackburn, Hart, \& Wainwright, 2013).

Tu (2011), a cluster of SMEs with limited marketing, has strengths and advantages over their small businesses' size. Thus, SMEs can quickly respond to markets, open up new consumer segments, access the latest markets, and build effective distribution, with a note of long as they have a cooperative strategy. Tu (2011) continued, the SME cluster marketing strategy also developed through many and diverse cluster members' distribution and network. Marketing strategies can spontaneously respond and then spread into broad marketing penetration.

In the aspect of financial strategy, SMEs have the characteristics of not having a legal entity so that it is unbankable, which amounts to 63 percent in Indonesia (Yustika, 2012). However, Prempanichnukul (2011) provides an argument about SME financial strategies developed through informal relationships with socio-cultural closeness in the community through debts. Access to informal capital is also more comprehensive with collateral and easier conditions, even with higher debt costs. Nilniyom \& Ratchatawetchakul (2011) added that SMEs' weak financial strategy, especially in the budget function and cost calculation, impacted the selling prices of SME products that were lower than the market. It makes SMEs with strong immunity during the crisis, albeit with low expansion and development power.

Next, a low-quality workforce tends to be responded to by optimizing the budget (Rajnoha \& Lorincova, 2015). It relates to the unpaid standardization of SME clusters, thus re- 
ducing production costs. On the other hand, SME workers' low expertise causes the development of new entrepreneurs to be higher because there is no barrier to entry. The same thing happened in the aspect of production technology strategy and operational innovation. Ogot (2014) put the government's central role to present to stimulate innovation and new and renewable technology.

\section{Data and Research Methods}

Data

This study uses two types of data, namely primary data and secondary data. Primary data were obtained from direct interview observations (in-depth interviews) using a questionnaire instrument. For data processing using the linear regression method, the questionnaire used comprises a linked scale with a range of 1-5. Deepening observations about SME Clusters' performance are mainly related to relationships with other similar clusters. Secondary data was obtained from previous observations in documentation, statistical data, empirical analysis, and expert recommendations.

The population of SME in Pasuruan City is 210 furniture SME units (Krapyakrejo Village, Gadingrejo District), while in Malang there are 140 furniture SME units (Tunjung Sekar Village, Kemirahan). Samples taken were 60 business units with the distribution of 30 business units in each city. The selection of respondents using a random sampling approach so that can select each member of the population. In-depth interviews carry out data collection techniques to determine business performance, interface linkage, and business strategy. Besides, a qualitative questionnaire was prepared with several questions to explore other information. These questions include: (1) Where do the raw materials come from?; (2) How to develop product innovation?; 3) Are there any efforts to develop innovation through technology?; (4) Who are the main partners in this business?; (5) Where are the products usually sold?; (6) How is the SWOT in this UKM cluster? What are the factors?

\section{Method}

The first step of this research is multiple linear regression analysis. It aims to find the effect of independent variables on the dependent variable in 60 samples of 360 population. According to Gujarati (2004), the regression model is a formal way to express two essential elements of a statistical relationship: (1) A tendency to change the dependent variable $Y$ systematically in line with changes in the large variable X. (2) The scattering of points in the statistical relationship curve ser. These two features are united in a regression model by postulating that: (1) There is a plan for the probability of variable $Y$ for each level (level) of variable X. (2) The average distribution of opportunities changes systematically in line with changes in the value of the variable $X$.

The regression analysis has three uses: (1) to describe data phenomena or cases under investigation. A regression can describe data phenomena through the formation of a numerical relationship model. (2) For control purposes, a regression can also be used to control (control) a case or things observed through the use of the regression model obtained. (3) as a prediction. Regression models can also be used to predict dependent variables.

The general form of the linear regression function can be written as follows:

$$
Y_{i}=\beta_{0}+\beta_{1} x_{1}+\beta_{2} x_{2}+\ldots+\varepsilon_{\mathrm{i}}
$$

Whereas:

$Y_{i}$ is the value of the dependent variable on observation $i$

$\beta_{0}$ is the Constanta on observation $i$

$\beta_{1}$ is the value of the variable coefficient on observation $i$ 
$X_{1}$ is the value of the independent variable on observation $i$

$\varepsilon_{i}$ is a random error term with a standard error (standard error)

Continuously, data analysis refers to Miles and Huberman's descriptive analysis approach (1992, in Moleong, 2017). The descriptive analysis consists of three main analysis components simultaneously since or concurrently with the data collection process. These components are data reduction, data presentation, and conclusions.

Table 1: Operational Definition of Variables

\begin{tabular}{|c|c|c|c|}
\hline Variables & Variables Detail & Definition & Linked Scale \\
\hline \multirow{5}{*}{ Dependent Variables } & Sales & Percentage of sales increasing & \multirow{5}{*}{$\begin{array}{c}\text { Stagnant (when } \\
\text { performance is the } \\
\text { same every year) }=1 \\
0-20 \%=2 \\
21 \%-40 \%=3 \\
41 \%-60 \%=4 \\
>61 \%=5\end{array}$} \\
\hline & Profit & Percentage of profit growth & \\
\hline & Assets & Percentage of assets growth & \\
\hline & Labor & Percentage of labor increment & \\
\hline & Productivity & Percentage of productivity growth & \\
\hline \multirow{3}{*}{$\begin{array}{l}\text { Independent Variables } \\
\text { (Cooperatives) }\end{array}$} & Backward Linkage & Intensity of Backward Linkage & \multirow{8}{*}{$\begin{array}{c}\text { Never }=1 \\
\text { Rare }=2 \\
\text { Sometimes }=3 \\
\text { Often }=4 \\
\text { Always }=5\end{array}$} \\
\hline & Forward Linkage & Intensity of Forward Linkage & \\
\hline & Horizontal Linkage & Intensity of Horizontal Linkage & \\
\hline \multirow{5}{*}{$\begin{array}{l}\text { Independent Variables } \\
\text { (Business Strategy) }\end{array}$} & Financial Strategy & $\begin{array}{l}\text { Intensity of used Financial Strat- } \\
\text { egy }\end{array}$ & \\
\hline & Marketing Strategy & $\begin{array}{l}\text { Intensity of used Marketing } \\
\text { Strategy }\end{array}$ & \\
\hline & Human Resource Strategy & $\begin{array}{l}\text { Intensity of used Human Resource } \\
\text { Strategy }\end{array}$ & \\
\hline & $\begin{array}{l}\text { Research and Develop- } \\
\text { ment Strategy }\end{array}$ & $\begin{array}{l}\text { Intensity of used Research and } \\
\text { Development Strategy }\end{array}$ & \\
\hline & Operational Strategy & $\begin{array}{l}\text { Intensity of used Operational } \\
\text { Strategy }\end{array}$ & \\
\hline
\end{tabular}

Finally, the Strength-Weaknesses-Opportunities-Threat (SWOT) matrix is a vital matching tool to help develop four types of strategies, namely SO (Strength-Opportunity) strategy, WO (Weakness-Opportunity) strategy, ST Strategy (Strength- Threat), and the WT (Weakness-Threat) strategy. In the SWOT matrix, data is obtained from in-depth interviews with all respondents about opportunities, challenges, threats, and obstacles in the SME cluster ecosystem. Also, data were obtained from literature studies on secondary data and previous research.

Tabel 2: SWOT Matrix Model

\begin{tabular}{|c|c|c|}
\hline $\begin{array}{ll}\mathrm{EFE} & \text { IFE } \\
\end{array}$ & Strengths (S) & Weaknesses (W) \\
\hline Opportunities (0) & SO Strategy & WO Strategy \\
\hline Threats (T) & ST Strategy & WT Strategy \\
\hline
\end{tabular}

\section{Finding and Discussion}

\section{Multiple Linear Regression: Relationship Cooperatives and Business Strategy to Business Performance}

Analysis of inter-firm linkage and business strategy on business performance was carried out using multiple linear regression. This process is carried out in several equations according to the dependent variable target. Thus, all independent variables from the inter-firm 
linkage (backward, horizontal and forward) and business strategy (finance, human resources, marketing, research and development, and operations) are regressed to the dependent variable business performance (sales, profits, assets, labor, and productivity).

Table 3 summarizes the estimated linear regression in linkage inter-firm modeling and business strategy. On sales performance, the forward linkage has a negative effect (-0.104886). It explains that increasing joint actions to build a network in the future can reduce sales performance. This contradictory relationship pattern is defined by the marketing strategy, which has a significant positive effect $(0.342434)$, concluding that the marketing and sales pattern is still at the level of each business unit's strategy. Or in other words, the Meubel UKM cluster prefers individual marketing strategies rather than joint actions for sales. In line with Wiechoczek (2016) explanation, marketing SMEs in developing countries compete until they tend to be cannibalistic. The majority of SMEs undertake individual marketing strategies to improve sales performance.

Table 3: Result of Multiple Linear Regression

\begin{tabular}{|c|c|c|c|c|c|c|}
\hline & \multirow{2}{*}{$\begin{array}{l}\text { Independent } \\
\text { Variables }\end{array}$} & \multicolumn{5}{|c|}{ Dependent Variables } \\
\hline & & Sales & Profit & Assets & Labor & Productivity \\
\hline & Konstanta & $\begin{array}{r}3.349195 \\
(4.327)^{*}\end{array}$ & $\begin{array}{r}3.094584 \\
(4.255)^{*} \\
\end{array}$ & $\begin{array}{r}2.441148 \\
(3.823)^{*}\end{array}$ & $\begin{array}{r}2.553941 \\
(4.160)^{*}\end{array}$ & $\begin{array}{r}2.877601 \\
(3.892)^{*} \\
\end{array}$ \\
\hline \multirow{3}{*}{$\begin{array}{l}\text { Inter-Firm } \\
\text { Linkage }\end{array}$} & $\begin{array}{c}\text { Backward } \\
\text { Linkage }\end{array}$ & $\begin{array}{l}0.023468 \\
(0.095)^{* *} \\
\end{array}$ & $\begin{array}{l}-0.070413 \\
(-0.305)^{* *} \\
\end{array}$ & $\begin{array}{r}-0.118075 \\
(-0.583)^{* * *} \\
\end{array}$ & $\begin{array}{r}-0.133234 \\
(-0.684)^{*} \\
\end{array}$ & $\begin{array}{l}-0.147411 \\
(-0.629)^{* *} \\
\end{array}$ \\
\hline & $\begin{array}{l}\text { Forward } \\
\text { Linkage }\end{array}$ & $\begin{array}{l}-0.104886 \\
(-0.552)^{* *}\end{array}$ & $\begin{array}{r}0.094766 \\
(0.531)^{*}\end{array}$ & $\begin{array}{r}0.008971 \\
(0.057322)^{* *}\end{array}$ & $\begin{array}{l}0.168240 \\
(1.118)^{* *}\end{array}$ & $\begin{array}{r}0.118792 \\
(0.655)^{*}\end{array}$ \\
\hline & $\begin{array}{l}\text { Horizontal } \\
\text { Linkage }\end{array}$ & $\begin{array}{r}0.322587 \\
(1.585)^{*}\end{array}$ & $\begin{array}{l}0.276975 \\
(1.448)^{* *}\end{array}$ & $\begin{array}{r}0.447254 \\
(2.663)^{*}\end{array}$ & $\begin{array}{l}-0.047153 \\
(-0.292)^{* *}\end{array}$ & $\begin{array}{r}0.210769 \\
(1.084)^{*}\end{array}$ \\
\hline \multirow{8}{*}{$\begin{array}{l}\text { Strategi } \\
\text { Bisnis }\end{array}$} & $\begin{array}{c}\text { Financial Strat- } \\
\text { egy }\end{array}$ & $\begin{array}{r}-0.222984 \\
(-1.168)^{* * *}\end{array}$ & $\begin{array}{l}-0.196520 \\
(-1.095)^{* *}\end{array}$ & $\begin{array}{r}-0.154613 \\
(-0.981)^{* * *}\end{array}$ & $\begin{array}{r}-0.021470 \\
(-0.141)^{* * *}\end{array}$ & $\begin{array}{r}-0.124241 \\
(-0.681)^{* * *}\end{array}$ \\
\hline & $\begin{array}{c}\text { Marketing Strat- } \\
\text { egy }\end{array}$ & $\begin{array}{r}0.342434 \\
(1.759)^{*}\end{array}$ & $\begin{array}{r}0.407873 \\
(2.230)^{*}\end{array}$ & $\begin{array}{r}-0.076387 \\
(-0.475)^{*}\end{array}$ & $\begin{array}{r}-0.093020 \\
(-0.602)^{* * *}\end{array}$ & $\begin{array}{r}0.279530 \\
(1.503)^{*}\end{array}$ \\
\hline & $\begin{array}{c}\text { Human Resource } \\
\text { Strategy }\end{array}$ & $\begin{array}{l}0.063044 \\
(0.530)^{* *}\end{array}$ & $\begin{array}{l}0.094704 \\
(0.848)^{* *}\end{array}$ & $\begin{array}{r}0.254023 \\
(2.592)^{*} \\
\end{array}$ & $\begin{array}{r}0.078553 \\
(0.833)^{*} \\
\end{array}$ & $\begin{array}{l}0.074186 \\
(0.653)^{* *} \\
\end{array}$ \\
\hline & $\begin{array}{c}\text { Research and } \\
\text { Development } \\
\text { Strategy }\end{array}$ & $\begin{array}{r}-0.432698 \\
(-2.490)^{* * *}\end{array}$ & $\begin{array}{l}-0.294481 \\
(-1.803)^{* *}\end{array}$ & $\begin{array}{l}-0.151683 \\
(-1.058)^{* *}\end{array}$ & $\begin{array}{r}-0.231198 \\
(-1.677)^{* * *}\end{array}$ & $\begin{array}{l}-0.189724 \\
(-1.143)^{* *}\end{array}$ \\
\hline & $\begin{array}{c}\text { Operational } \\
\text { Strategy }\end{array}$ & $\begin{array}{l}0.020782 \\
(0.159)^{* *}\end{array}$ & $\begin{array}{r}-0.196613 \\
(-1.310)^{* * *}\end{array}$ & $\begin{array}{l}-0.028735 \\
(-0.218)^{* *} \\
\end{array}$ & $\begin{array}{l}0.179453 \\
(1.416)^{* *}\end{array}$ & $\begin{array}{r}-0.134205 \\
(-0.879)^{* * *} \\
\end{array}$ \\
\hline & R-Squared & 0.454682 & 0.517861 & 0.416344 & 0.671138 & 0.504430 \\
\hline & D-W & 2.078496 & 2.009290 & 2.259728 & 2.050087 & 2.013071 \\
\hline & $\begin{array}{c}\text { F-stat } \\
\text { Prob (F-stat) }\end{array}$ & $\begin{array}{r}2.178399 \\
(0.000761)\end{array}$ & $\begin{array}{r}2.970607 \\
(0.000283)\end{array}$ & $\begin{array}{r}2.949868 \\
(0.000001)\end{array}$ & $\begin{array}{r}1.316270 \\
(0.000014)\end{array}$ & $\begin{array}{r}1.638127 \\
(0.000000)\end{array}$ \\
\hline
\end{tabular}

*Significant in a 1\%; **Significant in a 5\%; ***Significant in $\alpha 10 \%$

Source: Author's Calculation

The Meubel UKM cluster conducted a marketing strategy (0.407873) and development research (0.294481). Larrañaga Moreno \& Ortega Flores (2015) suggest that the operating profit range increases with decreasing risk and fixed costs (especially for the exhibition and promotion process). As for the inter-firm linkage, the horizontal association has a significant positive effect on increasing profits. As said by the SME furniture entrepreneurs, in the middle of the cluster, there has been a subcontract and suborder relationship that is going well. Among business units sharing orders to retain their fatalist consumers, suborder and subcon- 
tracting become choices (Akkrawimut \& Ussahawanitchakit, 2011).

The Asset Variable is estimated that horizontal linkage has a significant effect (0.447254) and is followed by a research development strategy. Garud \& Prasad (2013), UKM applies a simple research and development pattern related to capacity development (resulting in a knowledge spill-over), carried out this simple development research by utilizing conventional networks and information received through interactions with consumers. Due to SMEs' small capacity in each business unit, it makes it more responsive to changes in the market and business climate.

\section{SWOT Matrix Analysis of Furniture SME Cluster Malang City and Pasuruan City}

The industrial economics of Malang City and Pasuruan City have different characteristics (SWOT). So that in its development, the two regions can be interconnected to build inter-related cooperation in several UKM Clusters. This dynamic and reciprocal relationship between clusters is referred to as inter-clustering linkage (Oprime et al., 2011). Internal and external factors The SME cluster of the study area provides various interaction patterns that can then analyze. The furniture industry's inter-clustering linkage can provide a dynamic and reciprocal relationship pattern in the future that can adopt to build inter-clustering associations for other commodity clusters. SWOT matrix analysis is carried out by entering the results of in-depth interviews and literature studies into the SWOT table. Furthermore, the matrix results are obtained by connecting each intersecting SWOT section in the table.

Malang City has a strength in the number of furniture business units reaching 46 business units. Also, this is supported by the SME cluster furniture showroom, which has been compared to expand access to consumer demand. In this SO strategy, Malang City UKM Cluster optimizes the number of business units and showroom branding to take advantage of Malang City technology's access opportunities as the City of Education. So, the Malang City Furniture cluster's marketing has a pretty good brand with online marketing and a beautiful and comfortable place layout. Uzor (2004), consumer preferences are not limited to the need for certain goods and services but include the accompanying attributes such as brand, fashion, etc.

Table 4: SWOT Matrix of Furniture SME Cluster in Malang City

\begin{tabular}{|c|c|c|}
\hline${ }^{\mathrm{EFE}}{ }^{\text {IFE }}$ & Strengths (S) & Weaknesses (W) \\
\hline $\begin{array}{l}\text { Opportunities } \\
\text { (0) }\end{array}$ & 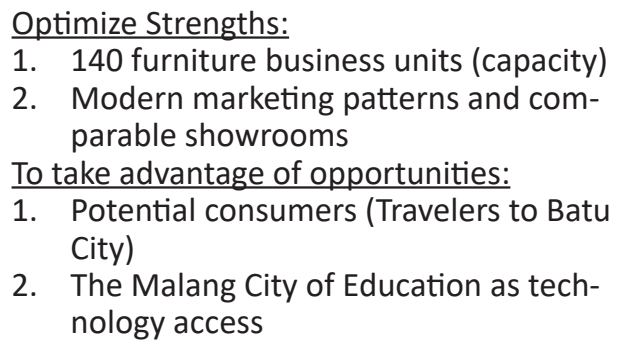 & $\begin{array}{l}\text { Manage Weaknesses: } \\
\text { 1. Access to limited raw materials } \\
\text { 2. The lack of skilled workers in the } \\
\text { field of furniture } \\
\text { To optimize opportunities: } \\
\text { 1. Potential consumers (Travelers to } \\
\text { Batu City) } \\
\text { 2. The Malang City of Education as } \\
\text { technology access }\end{array}$ \\
\hline Threats $(\mathrm{T})$ & $\begin{array}{l}\text { Optimize Strengths: } \\
\text { 1. } 140 \text { furniture business units (capacity) } \\
\text { 2. Modern marketing patterns and com- } \\
\text { parable showrooms } \\
\text { To suppress threats: } \\
\text { 1. Competition against similar clusters } \\
\text { 2. Globalization and market for fiber, } \\
\text { plastic, and imitation materials }\end{array}$ & $\begin{array}{l}\text { Manage Weaknesses: } \\
\text { 1. Access to limited raw materials } \\
\text { 2. Institutional Inter-Firm Linkage is still } \\
\text { not well established } \\
\text { To avoid threats: } \\
\text { 1. Competition against similar clusters } \\
\text { 2. Globalization and market for fiber, } \\
\text { plastic, and imitation materials }\end{array}$ \\
\hline
\end{tabular}

Source: Author's Illustration

This SO strategy is optimized to target consumer segmentation mainly because of its proximity to the Batu City tourist attraction. Central Bureau of Statistics for Batu City (2010) 
recorded at least 1,100,000 more foreign and domestic tourists coming to Batu City with a trend that continues to increase each year. So that Batu Tourism City and the Malang City of Education become opportunities that SME Cluster continuously optimizes in Malang City.

Access to advanced marketing technology and considerable consumer potential also needs to be maintained to continue to provide a climate of good performance in the cluster of SME furniture. However, this is faced with weaknesses. Malang City Furniture cluster SMEs have weaknesses in access to raw materials and skilled workers in the furniture sector. This weakness has occurred since early 2000, so that most furniture industries are looking for sources of semi-finished and finished furniture from other clusters, one of which is the $\mathrm{Pa}$ suruan City SME furniture cluster.

The SWOT analysis also shows the threat that the Malang cluster of Malang city furniture businesses is threatened by competition and globalization. It is related to imported products that are getting stronger with a variety of raw materials. However, this can be anticipated and dispelled by the branding of Malang City's established SME furniture cluster and the number of business units sufficient to meet consumer demand.

Finally, the WT strategy has the threat of global competition, which can be anticipated by managing weaknesses in limited access to raw materials and labor. As mentioned earlier, Malang City furniture industry entrepreneurs seek access to ready-made furniture or semi-finished furniture for polishing. The most significant furniture source is from the City of Pasuruan because of the competitive price and quality.

Tabel 5: SWOT Matrix of Furniture SME Cluster in Pasuruan City

\begin{tabular}{|c|c|c|}
\hline${ }_{\mathrm{EFE}}{ }^{\text {IFE }}$ & Strengths (S) & Weaknesses (W) \\
\hline $\begin{array}{l}\text { Opportunities } \\
\text { (0) }\end{array}$ & $\begin{array}{l}\text { Optimize Strengths: } \\
\text { a. 1,122 furniture business units (capacity) } \\
\text { b. 5,188 wood workforce and expert } \\
\quad \text { workforce have not yet worked } \\
\text { To take advantage of opportunities: } \\
\text { a. Raw material access to Pasuruan Re- } \\
\text { gency } \\
\text { b. The climate of the business environ- } \\
\text { ment with free land }\end{array}$ & $\begin{array}{l}\text { Manage Weaknesses: } \\
\text { a. Access to limited marketing (po- } \\
\text { tential consumers) } \\
\text { b. The marketing showroom is } \\
\text { incomparable } \\
\text { To optimize opportunities: } \\
\text { a. Raw material access to Pasuruan } \\
\text { Regency } \\
\text { b. The climate of the business envi- } \\
\text { ronment with free land }\end{array}$ \\
\hline Threats $(\mathrm{T})$ & $\begin{array}{l}\text { Optimize Strengths: } \\
\text { a. 1,122 furniture business units (capacity) } \\
\text { b. 5,188 wood workforce and expert } \\
\quad \text { workforce have not yet worked } \\
\text { To suppress threats: } \\
\text { a. Competition against similar clusters } \\
\text { b. Globalization and market for fiber, plas- } \\
\text { tic, and imitation materials }\end{array}$ & $\begin{array}{l}\text { Optimize Strengths: } \\
\text { a. } \begin{array}{l}1,122 \text { furniture business units } \\
\text { (capacity) }\end{array} \\
\text { b. } 5,188 \text { wood workforce and } \\
\text { expert workforce have not yet } \\
\text { worked } \\
\text { To suppress threats: } \\
\text { a. Competition against similar } \\
\text { clusters } \\
\text { b. Globalization and market for } \\
\text { fiber, plastic, and imitation } \\
\text { materials }\end{array}$ \\
\hline
\end{tabular}

Source: Author's Illustration

Contrastly with Malang City, the UKM cluster in Pasuruan City has the strength of many business units, around 1,122 units with 5,188 workers. It makes the Pasuruan City SME cluster have high productivity in labor and comparative advantage (Krugman et al., 2005). The rest of the Pasuruan City SME Cluster performance is also faced with opportunities for the accessibility of raw materials from the Pasuruan Regency. Also, about opportunities for expansion of production sites due to land availability. 
The Pasuruan City furniture cluster has weaknesses in the marketing aspect. Aside from access to SME Clusters' location that is quite far away with limited potential consumers is also related to showrooms that have not been adequately compared. Therefore, this continues to be minimized by marketing cooperation with similar clusters that excel in marketing aspects, especially Malang City. So this can optimize opportunities in the form of access to raw materials and a good business environment.

The SME cluster in Pasuruan City has the same threat as Malang City, a global competition. It is minimized by optimizing business units and skilled workers to win that price and quality competition. It is also related to engineering or managing weaknesses in the marketing aspect by building a cooperation network. This inter-clustering linkage in the next section will be revealed to obtain an established concept construction so that the next can be adopted as a pattern of developing SME Clusters.

\section{Finding of SME Inter-Clustering Linkage in East Java}

The previous section's SWOT Matrix analysis shows the internal and external factors of the two regions with some linkages and cooperation. The associations between furniture industry clustering are natural due to internal and external factors. The phenomenological analysis of the relations between these clusters begins with the ontology dimension, which originates the associations between UKM clusters. It originated from the decreasing supply of raw materials in the SME furniture cluster in Malang City, which originated from Bojonegoro Regency, Lumajang Regency, and Madiun Regency. This phenomenon of decreasing supply of raw materials occurs due to deforestation in some of these areas. It gradually affects the productivity of wood blocks that are ready to be processed in the furniture industry.

The same thing happened in the cluster of UKM in Pasuruan City with a different pattern of problems. In another case with Malang City, which has issues with raw materials, the UKM cluster in Pasuruan City has problems with marketing aspects due to its dynamics, especially transportation routes. Pasuruan is a small urban area that is less strategic in economic, geographic analysis. This area is not traversed by the flow of economic activity both by exchanging goods and labor. The north coast route from Surabaya to Probolinggo and Situbondo also passes outside the city so that the cluster of SME furniture lacks a strategic place for consumer segmentation. On the other hand, Pasuruan City access is far from technology development, especially marketing. So this further worsens the aspect of cluster marketing.

This background, which formed the cluster of SME furniture in both regions, has specialized in economic activity. Kota Pasuruan, with a comparative advantage over labor and availability of raw materials, focuses on developing production. The vision that continues to be promoted is production efficiency by developing labor skills and being selective about raw materials (Bhasin \& Venkataramany, 2010). Analysis of production costs is carried out to find a combination of minimum expenses with a certain production level. Also developed The $\mathrm{Pa}-$ suruan City furniture cluster through the gradual development of workforce capacity. As for raw materials, forest rejuvenation or reclamation has been carried out slowly from the nearest raw material source, Pasuruan Regency. So that the availability of labor and raw materials, in the long run, can be achieved to maintain the continuity of the SME Cluster.

On the other hand, Malang City, with the potential of marketing technology and its opportunities as a tourist city area, grows well-developing marketing aspects. The comparable showroom continues to be modified, marketing with various modes and methods used, to create various semi-finished furniture products into artistic furniture. Saptadi et al., (2014) including small and medium enterprises (SMEs emphasized that technology and innovation as value-added variables will maintain the business's survival. Besides the Malang City Furniture cluster, Malang integrates its showroom with travel agents. Furniture development for interi- 
or real estate also continues to be encouraged through architectural consulting services. The Malang City Furniture cluster has a technological advantage and marketing with added value.

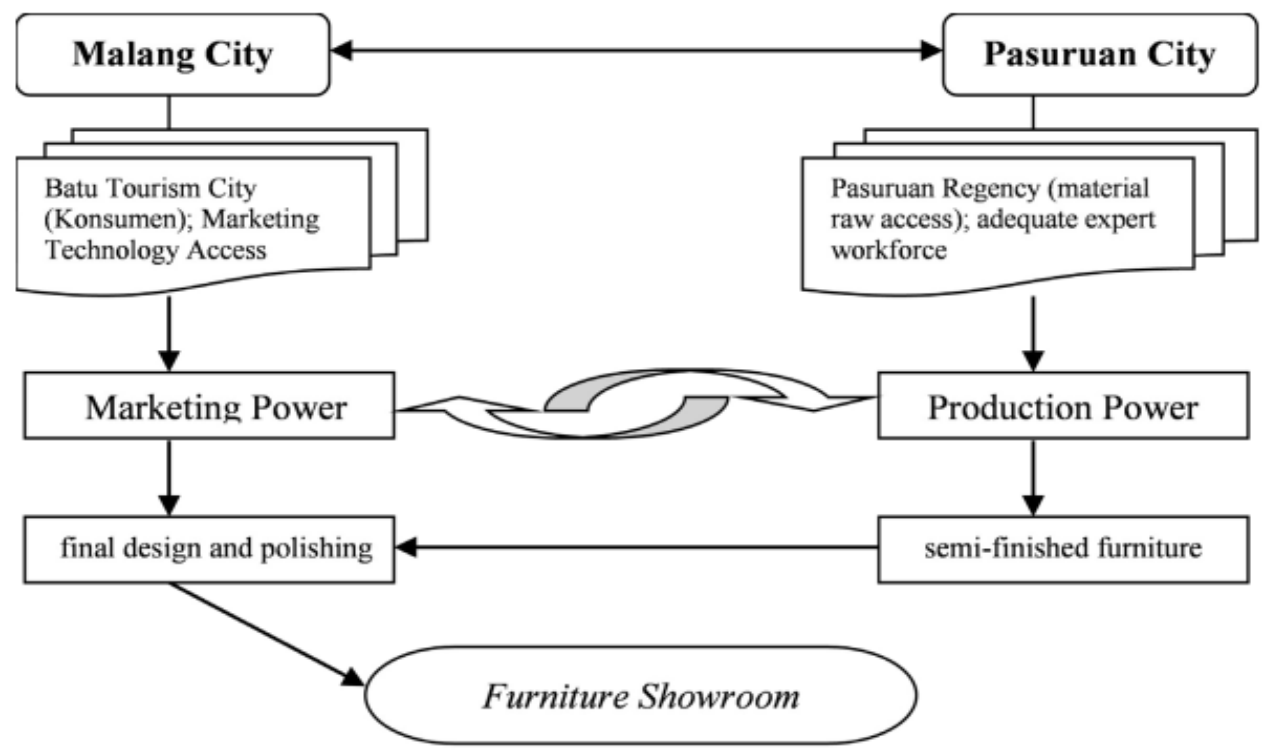

Figure 1: Pattern of Furniture SME Inter-Clustering Linkage

Source: Author's Illustration

The linkages between the two regions are carried out intensively. The high-productivity Pasuruan City SME furniture cluster sells half-finished and finished furniture to the Malang City SME furniture cluster. Next, Malang City Furniture cluster with technological excellence does the polishing to increase furniture products' added value. The rest of the products that are ready to sell are displayed in showrooms with various promotional modes, plus the development of interior furniture consultations. Such dynamic cooperation provides advantages for both clusters so that it can also maximize the potential and strengths of each region in addition to overcoming weaknesses.

\section{Conclusion}

The East Java Meubel UKM cluster is still one of the mainstays in the community's economy. The linear regression estimation performed shows the dominance of business strategies (especially marketing strategies, research development, finance, and human resources) rather than inter-firm linkage. It shows that the cluster performance (internally) has not worked optimally so that each business unit carries out its strategy individually. The business (marketing) strategy that was carried out primarily connected to the Meubel Cluster of Pasuruan City and Malang City proved to provide solutions to existing problems. This relationship between clusters is referred to as inter-clustering linkage.

The inter-clustering linkage of the Malang City and Pasuruan City furniture industry is caused by the decreasing supply of wood raw materials to Malang City due to deforestation. Pasuruan City has problems in marketing aspects due to the lack of strategic geographical position of regional economic activities. Both of these regions have specific strengths. Malang City has access to technological and marketing developments with the segmentation of tourist tourists. While Pasuruan City has strength in the workforce and access to raw materials, its productivity outperforms similar clusters. An inter-cluster linkage connects Pasuruan City's productivity constrained by marketing aspects to the marketing excellence of Malang City. The semi-finished furniture is polished in Malang City's UKM furniture cluster with various marketing modes and added with the development of interior consulting services. So this makes 
the two SME Clusters more dynamic and mutually supportive of achieving the highest performance. This kind of inter-clustering linkage pattern can be developed and adopted to develop same-sex SME Clusters that have strengths and weaknesses to complement each other in the dynamic performance of SME Clusters.

\section{References}

Aguilera-Castro, A., \& Virgen-Ortiz, V. (2016). Model for developing strategies specific to sme business growth. ENTRAMADO, 13(2), 30-40. https://doi.org/10.18041/entramado.2016v12n2.24204

Akkrawimut, K., \& Ussahawanitchakit, P. (2011). Dynamic Global Marketing Strategy and FirmSurvival: Evidence From Exporting Jewelry Businesses in Thailand. International Journal of Business Strategy, 11(2).

Belete, W. (2018). Determinants of Innovative Performance by Ethiopian Informal-Sector Micro and Small Enterprises (MSEs). Retrieved from https://openair.africa/wp-content/ uploads/2020/05/WP-13-Determinants-of-Innovative-Performance-by-Ethiopian-Informal-Sector-MSEs.pdf

Bhasin, B. B., \& Venkataramany, S. (2010). Globalization Of Entrepreneurship: Policy Considerations For SME Development In Indonesia. International Business \& Economics Research Journal (IBER), 9(4). https://doi.org/10.19030/iber.v9i4.557

Blackburn, R. A., Hart, M., \& Wainwright, T. (2013). Small business performance: business, strategy and owner?manager characteristics. Journal of Small Business and Enterprise Development, 20(1), 8-27. https://doi.org/10.1108/14626001311298394

Central Bureau of Statistics for Batu City. (2010). Statistik Kunjungan Wisatawan Mancanegara.

Garud, N., \& Prasad, L. (2013). Managerial Cognition in R\&D Processes Within Indian hi-tech firms: A Conceptual Framework. Journal of Entrepreneurship and Innovation Management, 2(3), 79-98. Retrieved from http://betadergi.com/jeim/yonetim/icerik/makaleler/13-published.pdf

Gujarati, D. N. (2004). Basic Econometric, Fourth Edition. New York.

Hoetoro, A. (2017). Ekonomika Industri Kecil. UP Press.

Hoetoro, A., \& Aditya Susanto, D. (2018). The Improvement of Inter-Firm Linkages Within Dormant Mse Cluster: a Case of East Java. International Journal of Engineering \& Technology, 7(3.30), 549. https://doi.org/10.14419/ijet.v7i3.30.18429

Kokobe Seyoum Alemu, B., \& Seyoum Alemu, K. (2015). Entrepreneurs' Characteristics as a Determinant of MSE Growth. Global Journal of Management and Business Research, 2(2), 8-24.

Krugman, P. R., Obstfeld, M., \& Melitz, M. J. (2005). International Economics: Theory And Policy, 7/E. Policy. New York: Pearson Education Inc.

Kusumah, L. H., \& Fetriyuna. (2014). The Implementation of Diagnosis Consultant (Sindanshi) Method in the Cluster of Food SMEs*. Journal of US-China Public Administration, 11(1), 84-95.

Larrañaga Moreno, M., \& Ortega Flores, M. T. (2015). Identification of innovation capabilities for micro and small enterprises in Morelos, Mexico. Global Conference on Business and Finance Proceedings, 10(1), 321-330.

Mawardi, M. K., Choi, T., \& Perera, N. (2011). The Factors of SME Cluster Developments in a Developing Country: the case of Indonesian clusters. ICSB World Conference Proceedings, 1-28. Retrieved from http://search.proquest.com/docview/922575128?accountid $=10297 \% 0$ A

Moleong, L. J. (2017). Metodologi Penelitian Kualitatif (Edisi Revisi). In PT. Remaja Rosda 
Karya (p. 424). Bandung.

Najib, M., Kiminami, A., \& Yagi, H. (2011). Competitiveness of Indonesian Small and Medium Food Processing Industry: Does the Location Matter? International Journal of Business and Management, 6(9). https://doi.org/10.5539/ijbm.v6n9p57

Navas-Alemán, L., Pietrobelli, C., \& Kamiya, M. (2012). Inter-Firm Linkages and Finance in Value Chains. IDB, 1-49.

Nilniyom, P., \& Ratchatawetchakul, Y. (2011). Cost Information Effectiveness Of Thai Electronic Business: Effect On Decision Making Advantage. International Journal of Business Strategy, 11(2), 111-122.

Ogot, M. (2014). Evidence on Challenges Faced by Manufacturing Informal Sector Micro-Enterprises in Nairobi and Their Relationship with Strategic Choice. International Business Research, 7(6). https://doi.org/10.5539/ibr.v7n6p119

Oprime, P. C., Tristão, H. M., \& Pimenta, M. L. (2011). Relationships, cooperation and development in a Brazilian industrial cluster. International Journal of Productivity and Performance Management, 60(2), 115-131. https://doi.org/10.1108/17410401111101467

Prempanichnukul, V. (2011). The Role of Budgeting Ethic Orientation on Managerial Performance: An Empirical Investigation of Thailand's Exporters. International Journal of Business Strategy, 11(2), 132-142.

Rajnoha, R., \& Lorincova, S. (2015). Strategic Management of Business Performance Based on Innovations and Information Support in Specific Conditions of Slovakia. Journal of Competitiveness, 7(1), 3-21. https://doi.org/10.7441/joc.2015.01.01

Rangkuti, F. (2005). Analisis SWOT Teknik Membelah Kasus Bisnis. Jakarta: PT Gramedia Pustaka.

Saptadi, S., Sudirman, I., Samadhi, T. A., \& Govindaraju, R. (2014). E-Business Initiatives in Indonesian Manufacturing SMEs. Jurnal Teknik Industri, 16(2). https://doi.org/10.9744/ jti.16.2.139-148

Saraceni, A. V., \& de Andrade Júnior, P. P. (2012). Analysis of aspects of innovation in a Brazilian cluster. Journal of Technology Management and Innovation, 7(3), 207-213. https:// doi.org/10.4067/s0718-27242012000300017

Setyawan Agus, A., Isa, M., Wajdi, W. F. M., Syamsudin, \& Nugroho Permono, S. (2015). An Assessment of SME Competitiveness in Indonesia. Journal of Competitiveness, 7(2), 60-74. https://doi.org/10.7441/joc.2015.02.04

Tambunan, T. (2006). Perkembangan Industri dan Kebijakan Industrialisasi di Indonesia Sejak Era Orde Baru Hingga Pasca Krisis.

Tambunan, T. (2008). Development of Rural Manufacturing SME Clusters in a Developing Country: The Indonesian Case. Journal of Rural Development, 31(1), 1-24.

Tu, H. (2011). Cluster Marketing Models and Strategies: The Implications Thereof in the Chinese High-Tech Industry. International Journal of China Marketing, 1(2), 12.

UNICO. (2011). The Cooperation for Strengthening Clusters (Sentra) of Small and Medium Industries in The Republic of Indonesia. Retrieved from https://openjicareport.jica.go.jp/ pdf/12025581.pdf

UNIDO. (2001). Development of Clusters and Networks of SMEs. Organization, 36.

Urban, S., Mayrhofer, U., \& Nanopouluos, P. (2000). Interfirm Linkages : The European Experience. In International Collaborative Partnership (pp. 1-27). Retrieved from http:// postel-vinay.net/osi/McmillanRev2000.PDF

Uzor, O. O. (2004). Small and Medium Scale Enterprises Cluster Development in South-Eastern Region of Nigeria. Retrieved from http://www.iwim.uni-bremen.de/files/dateien/1615_b086.pdf 